\author{
KRZYSZTOF PODWYSOCKI \\ Katedra Zoologii Bezkręgowców i Hydrobiologii \\ Uniwersytet Łódzki \\ Banacha 12/16, 90-237 Łódź \\ E-mail: krzysztof.podwysocki.biol@gmail.com
}

\title{
WPŁYW EKSPLOATACJI KONKRECJI POLIMETALICZNYCH NA RÓŻNORODNOŚĆ BIOLOGICZNA
}

\section{WSTEP}

Konkrecje polimetaliczne (konkrecje manganowe) to zalegające na dnie oceanów skupienia wielu minerałów (zwłaszcza uwodnionych tlenowodorotlenków manganu i żelaza, zawierające istotne ilości miedzi, niklu, kobaltu i pierwiastków ziem rzadkich - ang. rare earth elements, REE) o dość różnorodnej budowie, powstajace w wyniku wytracania $z$ wody i osadzania się wokół jąder konkrecji (np. zębów rekina) (HAN i współaut. 1997, LODGE 2002, KosLOW 2007, KOTLIŃSKI 2011, ZHANG i współaut. 2012, KOTLIŃSKI i współaut. 2015). Występuja na dnie Pacyfiku i Oceanu Indyjskiego oraz Atlantyku (KosLOW 2007, KotLIŃSKI 2011), przy czym szczególnie zasobny jest obszar Clarion-Clipperton Zone (Clarion-Clipperton Fracture Zone, CCFZ, CCZ), położony $\mathrm{w}$ północnowschodniej części Pacyfiku między $5^{\circ} \mathrm{N}$ a $20^{\circ} \mathrm{N}$ oraz pomiędzy $160^{\circ} \mathrm{W}$ a $115^{\circ} \mathrm{W}$ (ABRAMOWSKI i KOTLIŃSKI 2011, KOTLIŃSKI 2011, ABRAMOWSKI i STOYANOVA 2012). Konkrecje nie występuja jedynie na szelfach kontynentalnych, co zwiazane jest $z$ nadmiernym, turbulentnym ruchem wody (PAUTOT i MELGUEN 1975, CLARK i NEUTRA 1983, HAN i współaut. 1997, Mewes i współaut. 2014) oraz ze zbyt dużym dopływem materiału terygenicznego $z$ lądu, uniemożliwiającego wytrącanie się minerałów $z$ wody (PAUTOT i MELGUEN 1975, Clark i NeUtra 1983, Han i współaut. 1997, KosLOw 2007). Dodatkowo, lokalna morfologia dna, która bywa mocno urozmaicona, wpływa na rozmieszczenie konkrecji i ich skład chemiczny, co czyni obszar CCZ najzasobniejszym w konkrecje polime- taliczne (KoDAGALI 1988). Wykazano również, że substancje chemiczne sa dostarczane do wody $z$ kominów hydrotermalnych i tworza konkrecje hydrotermalne (w odróżnieniu od konkrecji hydrogenicznych) (PAUTOT i MELGUEN 1975, LI i współaut. 1997, MEWES i współaut. 2014), szczególnie aktywnych na grzbietach śródoceanicznych (PAUTOT i MELGUEN 1975). Do przyrastania konkrecje wymagają dodatkowo środowiska utleniajacego (HAN i współaut. 1997, MEwES i współaut. 2014) oraz odpowiednich warunków do życia mikroorganizmów, które biora udział $\mathrm{w}$ ich powstawaniu (HAN i współaut. 1997). Badania mikroorganizmów wewnątrz konkrecji dowiodły, że w konkrecjach zachodza procesy utleniania manganu (BLÖTHE i współaut. 2015) oraz wykazano, że mikroorganizmy biora udział $\mathrm{w}$ formowaniu konkrecji $\mathrm{w}$ procesach biomineralizacji, czyli wbudowywaniu przez organizmy minerałów pochodzących $z$ wody (WANG i współaut. 2009). Konkrecje polimetaliczne zostały odkryte podczas badań w trakcie rejsu okrętu Challenger w latach 1872-1876 (BLUHM 1994). Ich sposób powstawania (zwłaszcza udział mikroorganizmów) i prawidłowości rozmieszczenia nie są dotychczas w pełni poznane (BAKER i BEAUDOIN 2013).

$\mathrm{Na}$ dnie oceanicznym konkrecje manganowe stanowia jedyne twarde podłoże, niezbędne do występowania bentosu sesylnego - przytwierdzonego do podłoża (ClARK i NEUTRA 1983; MULLINEAUX 1987; RADZIEJEWSKA i KotLIŃSKI 2002; KosLOW 2007; GOODAY i współaut. 2015; GLOVER i współaut. 2016a, b). To właśnie przedstawiciele bentosu sa najliczniejsza grupa organizmów żyjących na 
obszarach zalegania konkrecji polimetalicznych i moga one zasiedlać do $10 \%$ konkrecji (BAKER i BEAUDOIN 2013). Szczególnie licznymi organizmami bentosowymi sa przedstawiciele takich grup jak: Foraminifera (otwornice), Porifera (gąbki), Bryozoa (mszywioły) i Ascidiacea (żachwy) (KOSLOW 2007, BAKER i BEAUDOIN 2013), lecz dominuja gąbki (LIM i współaut. 2017). Organizmy bentosowe, a zwłaszcza Anthozoa (koralowce), praktycznie nie wystepuja w osadach poza konkrecjami (VANREUSEL i współaut. 2016). Oprócz bentosu sesylnego, liczna grupe stanowia również ryby i strzykwy (BAKER i BEAUDOIN 2013), a także unikatowa dla konkrecji polimetalicznych fauna szczelinowa (ang. crevice fauna), która zasiedla spękania w konkrecjach i składa się głównie $z$ Nematoda (nicienie) i Harpacticoida (widłonogi) (THIEL i współ 1993). Rozmieszczenie, skład gatunkowy, rozrodczość i biomasa organizmów zależą od wielkości fauny (makrofauna i mejofauna cechują się szerszym zakresem występowania niż megafauna), głębokości, zasolenia (JANSSEN i współaut. 2015), temperatury (BAKER i BEAUDOIN 2013), rodzaju osadów, wielkości i obfitości konkrecji polimetalicznych (DE SMET i współaut. 2017) oraz tempa ewolucji organizmów (JANSSEN i współaut. 2015). Jednak najsilniejsza determinantą różnorodności biologicznej organizmów obszarów konkrecji polimetalicznych jest produktywność, której niskie wartości w największym stopniu wpływają na bioróżnorodność i unikatowość fauny tych obszarów (MORNANT i Gourbault 1990, BAKER i BEAUDOIN 2013, GLOVER i współaut. 2016a, VANREUSEL i współaut. 2016, DE SMET i współaut. 2017). O unikatowości fauny konkrecji manganowych świadczy również fakt, że sa to przede wszystkim organizmy osiadłe, m.in. Porifera, lub o ograniczonych możliwościach dyspersji, np. Isopoda, Tanaidacea (GLOVER i współaut. 2016b, KAISER i współaut. 2017, LIM i współaut. 2017). Choć wiedza o biologii fauny dna oceanicznego jest niekompletna (JANSSEN i współaut. 2015, AMON i współaut. 2016, DE SMET i współaut. 2017, BŁAŻEWICZ i współaut. 2019), to wiadomo, że zagęszczenie organizmów jest znacznie mniejsze niż na szelfie kontynentalnym, podczas gdy różnorodność gatunkowa jest wysoka (RADZIEJEWSKA i KOTLIŃSKI 2002, BAKER i BEAUDOIN 2013). Poprawie wiedzy o bogactwie życia tych obszarów służą projekty realizowane na obszarze $\mathrm{CCZ}$, takie jak m.in. Abyssline (GoODAY i współaut. 2015, AMON i współaut. 2016). Clarrion-Clipperton Zone wydaje się być jednym $z$ najlepszych obszarów badawczych, gdyż obfitość konkrecji powoduje, że jest najczęściej rozpatrywany pod katem podwodnego kopalnic- twa, a jednocześnie heterogeniczność habitatów stwarza warunki dla relatywnie dużej różnorodności biologicznej (CLARK i NEUTRA 1983, JANSSEN i współaut. 2015, KAISER i współaut. 2017). Dno na tym obszarze cechuje się silnym urozmaiceniem, a trofizm wody również różni się lokalnie (LAMBSHEAD i współaut. 2003, KAISER i współaut. 2017). Zróżnicowanie przestrzenne czynników środowiskowych, a także dominacja form sesylnych, wpływaja na formowanie się izolowanych populacji na tym obszarze (LAMBSHEAD i współaut. 2003, KAISER i współaut. 2017). Konkrecje polimetaliczne, jako twardy substrat wśród miękkiego osadu, stanowią biogeograficzne wyspy, przez co populacje zamieszkujacych je zwierzat były izolowane i ewoluowały niezależnie od innych populacji (brak przepływu genów), o czym świadczy obecność wielu gatunków nowych dla nauki (CLARK i NEUTRA 1983, RADZIEJEWSKA i KOTLIŃSKI 2002, GOODAY i współaut. 2015, Glover i współaut. 2016b).

Obecnie, od lat 50. i 60. XX w., w zwiaz$\mathrm{ku}$ z wyczerpywaniem się lądowych zasobów surowców metalicznych (zwłaszcza miedzi, kobaltu, niklu i cynku), konkrecje polimetaliczne postrzega się głównie przez pryzmat ich potencjalnego wydobywania i wykorzystania minerałów, $z$ których sa zbudowane (ABRAMOWSKI i KOTLIŃSKI 2011, ABRAMOWSKI i STOYANOVA 2012, Koslow 2007). W latach 60. XX w. J. L. Mero podjął się próby oszacowania ich zasobności i stwierdził, że wydobywajac jedynie 10\% konkrecji nagromadzonych na dnie oceanicznym można zapewnić odpowiednie dostawy surowców dla przemysłu na tysiace lat, czyli stanowiłyby odnawialne źródło metali, gdyż tempo ich wzrostu byłoby szybsze niż tempo wykorzystania (Koslow 2007). Później okazało się, że wartości te sa znaczaco przeszacowane i przy tempie przyrostu konkrecji $1 \mathrm{~mm} / \mathrm{mln}$ lat wydobycie nie byłoby kompensowane przez formowanie nowych konkrecji polimetalicznych (Koslow 2007). Mimo to, rozpoczęła się ożywiona dyskusja dotyczaca prawa własności na otwartym morzu, co doprowadziło do uchwalenia Konwencji o Prawie Morza w 1982 r. oraz powstania w 1994 r. ISA (ang. International Seabed Authority), agencji ONZ regulujacej wydobycie surowców oceanicznych znajdujacych się poza obszarem jurysdykcji poszczególnych państw (LODGE 2002, KOSLOW 2007, ABRAMOWSKI i KOTLIŃSKI 2011, ABRAMOWSKI i STOYANOVA 2012, KIM 2017, SZAMAŁEK 2018). Plany masowego wydobywania konkrecji, przy jednoczesnej dużej różnorodności biologicznej fauny tych obszarów i ewidentnego, negatywnego wpływu górnictwa dennego na środowisko, powoduja, że temat cieszy się i będzie się cieszył w przyszłości 
dużym zainteresowaniem (DE SMET i współaut. 2017). Zwiększanie wiedzy dotyczacej wpływu eksploatacji konkrecji manganowych na środowisko jest jednym $z$ najbardziej zaniedbanych aspektów podwodnego górnictwa (ClARK i NEUTRA 1983, BLUHM 1994, JANSSEN i współaut. 2015, JONES i współaut. 2017). Wiedza na temat zaburzeń środowiska powodowanych eksploatacja konkrecji manganowych pozwoli zatrzymać, a przynajmniej ograniczyć wydobywanie konkrecji, a także spowoduje przemyślane wyznaczenie stref ochronnych.

\section{RÓŻNORODNOŚĆ BIOLOGICZNA OBSZARÓW KONKRECJI POLIMETALICZNYCH}

Pod względem biomasy, dominujacca grupę organizmów związanych $z$ konkrecjami polimetalicznymi stanowia bakterie (BAKER i BEAUDOIN 2013, BLÖTHE i współaut. 2015), głównie bakterie utleniajace mangan (WANG i współaut. 2010, BLÖTHE i współaut. 2015), m.in. Proteobacteria (WANG i współaut. 2010). Większą różnorodność mikroorganizmów zaobserwowano jednak w osadach wokół konkrecji niż na nich (WU i współaut. 2013, SHulse i współaut. 2017), podczas gdy odwrotna zależność dotyczy przedstawicieli Archaea (Wu i współaut. 2013). Mikroorganizmy stanowia najistotniejszy element sieci troficznych i obiegu węgla w strefie przydennej oceanów (CLARK i NEUTRA 1983). Najważniejszym producentem oligotroficznych, otwartych oceanów sa Cyanobacteria (sinice) (HyUN i współaut. 1998). Do drugiej najliczniejszej grupy niewielkich organizmów należą otwornice (MULLINEAUX 1987, AMON i współaut. 2016). Tworza one na powierzchni konkrecji tuby, tunele lub maty, a nieliczne żyją również w osadach w sassiedztwie konkrecji (MullineauX 1987, GoOdAY i współaut. 2015). Otwornice należą do różnych gildii troficznych, choć dominuja filtratory (MullineauX 1987, BAKER i BeAudOIN 2013). Ich obfitość, a także zdolność do akumulacji manganu $z$ wody i odkładania w konkrecjach sugerują, że moga się one przyczyniać do przyrostu konkrecji (DUGOLINSKY 1976, MulLineaux 1987, KosLOW 2007).

Dominujacymi przedstawicielami mejofauny (organizmy o rozmiarach od 0,032 do $0,5 \mathrm{~mm}$ ) sa nicienie (MORNANT i GOURBAULT 1990, THIEL i współaut. 1993, RADZIEJEWSKA i KOTLIŃSKI 2002, MILJUTINA i współaut. 2010, BAKER i BEAUDOIN 2013), stanowiace $82 \%$ mejofauny występującej do $3 \mathrm{~mm}$ grubości osadu (RADZIEJEWSKA i KoTLIŃSKI 2002, MiLuUTinA i współaut. 2010). Różne rodziny nicieni mają swoja specyficzność dotyczacca siedliska. Jedne występuja w osadach w sa- siedztwie konkrecji, m.in. Microlaimidae, a inne w szczelinach i na powierzchni konkrecji, m.in. Desmodoridae (THIEL i współaut. 1993, RADZIEJEWSKA i KOTLIŃSKI 2002). Najliczniejsza rodzina nicieni są Monhysteridae (MORNANT i GourbaulT 1990). Co najmniej 5 rodzajów (Metaparoncholaimus, Micoletzkyia, Ironella, Perepsilonema i Spirinia) występuje wyłącznie na obszarach konkrecji polimetalicznych (RADZIEJEWSKA i KOTLIŃSKI 2002). Wykazano, że 2/3 gatunków nicieni stanowią mułożercy (MILJUTINA i współaut. 2010), dlatego fitodetrytus denny istotnie zwiększa gęstość nematofauny (RADZIEJEWSKA i KoTLIŃSKI 2002, BAKER i BEAUDOIN 2013).

Równie licznymi przedstawicielami mejofauny konkrecji manganowych sa widłonogi $z$ rodziny Harpacticoida (RADZIEJEWSKA i KOTLIŃSKI 2002), które, podobnie jak nicienie i larwy skorupiaków, stanowią dominujaca grupę fauny szczelinowej, choć w szczelinach konkrecji można znaleźć również rzadziej występujacych przedstawicieli Tardigrada i Polychaeta (THIEL i współaut. 1993). Jak podaje THIEL i współaut. (1993), fauna szczelinowa zasiedla wewnętrzne spękania w konkrecjach wypełnione mułem i może znacznie różnić się składem gatunkowym od osadów leżacych pomiędzy konkrecjami.

Makrofauna (osobniki o rozmiarach od 0,3 do 0,5 mm) jest zróżnicowana gatunkowo, lecz cechuje się małym zagęszczeniem organizmów, które dodatkowo osiagają niewielkie rozmiary (BAKER i Beadoin 2013). Wśród makrofauny dominują Polychaeta (wieloszczety) (BAKER i BEAUDOIN 2013, JANSSEN i współaut. 2015). Żyja głównie w osadach i wykazują duże zróżnicowanie sposobu odżywiania, przy czym dominuja filtratory (JANSSEN i współaut. 2015). Dowiedziono, że różnorodność wieloszczetów zależy w dużym stopniu od produktywności oraz, w mniejszym stopniu, od rodzaju osadów i obfitości konkrecji polimetalicznych (DE SMET i współaut. 2017). Jednym z dominujących taksonów są również kolonijne, osiadłe Bryozoa (BLUHM 1994), dla których konkrecje polimetaliczne stanowia twarde podłoże (Glover i współaut. 2016a, b).

Wśród przedstawicieli skorupiaków dominują głównie Isopoda i Tanaidacea, które cechuja się bardzo niewielka mobilnością form dorosłych oraz brakiem larw planktonicznych, co sprawia, że maja one bardzo ograniczone możliwości dyspersji i na obszarach konkrecji spotykane sa izolowane populacje tych zwierzat (GLOVER i współaut. 2016b).

Największe organizmy zaliczane sa do megafauny, definiowanej jako fauna możliwa do rozpoznania na podstawie fotografii (BLUHM 1994, RADZIEJEWSKA i KOTLIŃSKI 2002, BAKER i BEAUDOIN 2013). Obejmuje 
ryby, głowonogi, szkarłupnie, gąbki, parzydełkowce (głównie koralowce), skorupiaki, a także dorastajace do $20 \mathrm{~cm}$ otwornice $\mathrm{z}$ grupy Xenophyophorea (BAKER i BEAUDOIN 2013). Wśród form porastających konkrecje dominuja gąbki, podczas gdy w osadach w sasiedztwie konkrecji przeważaja strzykwy (BLUHM 1994, RADZIEJEWSKA i KOTLIŃSKI 2002, VANREUSEL i współaut. 2016) i wężowidła (AMON i współaut. 2016, VANREUSEL i współaut. 2016). Zagęszczenie gatunków żyjących w osadach jest w niewielkim stopniu zależne od obecności konkrecji, ale na obszarach pozbawionych konkrecji było mniejsze (VANREusel i współaut. 2016). Z powodu większych rozmiarów przedstawicieli megafauny niż pozostałych grup, ich zagęsczenie silniej zależy od rozmiaru konkrecji (MULLINEAUX 1987).

Reasumujac, konkrecje polimetaliczne stanowia twardy substrat, na którym moga osadzić się organizmy bentosu sesylnego, m.in.: Foraminifera, Porifera i Bryozoa, oraz bentosu wagilnego, m.in.: Polychaeta, Nematoda i Harpacticoida. Blisko $70 \%$ makrofauny i megafauny stanowia filtratory (MULLINEAUX 1987). Specyficzne podłoże jakie stanowia konkrecje $\mathrm{w}$ porównaniu $\mathrm{z}$ otoczeniem oraz występowanie głównie form bentosowych o ograniczonej możliwości dyspersji, czynia faunę tych obszarów unikatową. Przykładowo, w badaniach w ramach projektu Abyssline w Clarion-Clipperton Zone ponad połowa zebranych gatunków była nowa dla nauki (AMON i współaut. 2016). W przypadku Tanaidacea było to nawet 95\% (BŁAŻEWICZ i współaut. 2019), co podkreśla wciąż niewielką znajomość różnorodności dna oceanicznego (PURSER i współaut. 2016) i wskazuje na wyjątkowa specyficzność jego fauny.

\section{EKSPLOATACJA KONKRECJI POLIMETALICZNYCH}

Jak podają BuRns (1980), OEBIUS i współaut. (2001), ABRAMOWSKI i KOTLIŃSKI (2011), ABRAMOWSKI i STOYANOVA (2012) oraz BAKER i BEAUDOIN (2013), wydobywanie konkrecji polimetalicznych ma składać się $z$ następujących etapów:

- pobór konkrecji metoda hydrauliczna z dna przy wykorzystaniu urządzeń zdalnie sterowanych (podwodne kombajny);

- transport wstepnie przemytych konkrecji ku górze w kierunku statku lub platformy;

- opróżnianie rury transportowej i usuwanie wody po odwodnieniu surowca;

- transport statkiem do portu lub magazynów.
$\mathrm{Na}$ wszystkich wymienionych etapach istnieja zagrożenia dla lokalnej, ale także regionalnej różnorodności biologicznej. Wstępne badania, polegajace na eksperymentalnym wydobyciu konkrecji w ramach badań środowiskowych (np. Benthic Impact Experiment, BIE), prowadziły do powstania silnej zawiesiny $\mathrm{w}$ warstwie wód przydennych oraz zaburzenia osadów dna, co pokazało wyraźnie negatywny wpływ eksploatacji konkrecji manganowych na różnorodność biologiczna (BLUHM 1994, AHNERT i SCHRIEVER 2001, KOSLOW 2007, BAKER i BEAUDOIN 2013, JANSSEN i współaut. 2015, JONES i współaut. 2017). Na szczególna uwagę zasługuje fakt, że obszary cechujące się wyjątkową gęstościa konkrecji, a więc korzystne $z$ ekonomicznego punktu widzenia, sa zwykle zasiedlone również przez silnie zróżnicowana faunę, gdyż czynniki takie jak niskie tempo sedymentacji oraz słabe pracdy przydenne wpływają pozytywnie zarówno na formowanie się konkrecji, jak i życie organizmów bentosowych (VANREUSEL i współaut. 2016). Eksploatacja konkrecji będzie miało zatem szczególnie negatywny wpływ na różnorodność fauny $z$ nimi zwiąanej. Wpływ ten na środowisko można podzielić na 4 obszary: dno oceaniczne, toń oceaniczna, powierzchnia wody i wybrzeża.

\section{WPŁYW EKSPLOATACJI KONKRECJI POLIMETALICZNYCH NA DNO OCEANICZNE}

Pierwsza oczywistą konsekwencja wydobycia konkrecji polimetalicznych będzie zaburzenie i niszczenie przez podwodne kombajny osadów, wraz $z$ zasiedlajaca je fauna (BurNs 1980, BLuHM 1994, OEBIUs i współaut. 2001, KAISER i współaut. 2017). Kombajny będą również zbierać podłoże (konkrecje i osady), na którym żyja organizmy bentosowe (OEBIUs i współaut. 2001). Jak pokazuja podwodne zdjęcia, obszar, na którym pracował kombajn (nawet do $100 \mathrm{~m} \mathrm{od}$ drogi poruszania się urządzenia), jest doszczętnie zniszczony, zarówno pod względem osadów, jak i fauny (BuRNS 1980). Kombajny będac powodować również wzbijanie się osadów, ich przenoszenie przez przydenne prady na pewne odległości oraz osiadanie, co doprowadzi do przysypywanie żyjących tam organizmów oraz utrudnione zdobywanie pożywienia, choć brak wiedzy odnośnie przydennych prąów uniemożliwia dokładnie stwierdzenie jakiego obszaru będzie to dotyczyć i $z$ jaka intensywnością przebiegnie (BURNS 1980, Clark i NEUTRA 1983, OEBIUS i współaut. 2001, VAN DOVER i współaut. 2017). Projektowane kombajny maja za zadanie wyłapywać i zmniejszać odległość na 
jaka wzruszone osady będą się przemieszczać, lecz z drugiej strony, tłumienie podnoszenia się tych osadów spowoduje ich bardziej burzliwy ruch, który również może stanowić zagrożenie dla bentosu (OEBIUS i współaut. 2001).

Wydobycie konkrecji spowoduje usunięcie wierzchnich warstw osadów, czego konsekwencja będzie zniszczenie fauny żyjącej na konkrecjach i w osadach (BLUHM 1994, KoSLOW 2007, BAKER i BEAUDOIN 2013, AMON i współaut. 2016), co będzie szczególnie niekorzystne dla organizmów sesylnych i fauny szczelinowej, które nie będą wstanie uciec (AMON i współaut. 2016).

Fauna dna oceanicznego ewoluowała w bardzo stabilnych warunkach, dlatego zaburzenia zwiazzane $z$ kopalnictwem spowoduja spadek zagęszczenia makrofauny nawet do 90\% (KosLOW 2007). Stopień zubożenia fauny zależeć będzie od rozmiarów i grup funkcjonalnych zwierząt, warunkujących ich różną wrażliwość na zaburzenia (JoNEs i współaut. 2017).

Znaczną część organizmów głębokowodnych cechuje powolny wzrost $\mathrm{i}$ niskie tempo reprodukcji (BAKER i BEAUDOIN 2013). Uważa się zatem, że zniszczenie zespołów bentosowych będzie procesem nieodwracalnym, gdyż zespoły te nigdy się nie zregeneruja lub proces ten będzie znacznie dłuższy niż w przypadku ekosystemów szelfu kontynentalnego i lądowych, a niektórzy naukowcy uważaja, że może trwać nawet tysiace lat (CLARK i NEUTRA 1983, KOSLOW 2007, AMON i współaut. 2016, PURSER i współaut. 2016, VANREUSEL i współaut. 2016, KAISER i współaut. 2017, VAN DOVER i współaut. 2017). Problem regeneracji zespołów sesylnych jest zwiazany również $z$ bardzo powolnym wzrostem konkrecji manganowych (VANREUSEL i współaut. 2016, KAISER i współaut. 2017). Jest wielce prawdopodobne, że działania gospodarcze całkowicie wyeliminuja gatunki sesylne, a pozostana jedynie formy mobilne (BAKER i BEAUDOIN 2013). Dotychczas przeprowadzono wiele eksperymentalnych zaburzeń dna, m.in. DISCOL, i porównano różnorodność biologiczna przed i kilka lat po eksperymencie. Badania w południowo-wschodnim Pacyfiku wykazuja, że eksperymentalne zaburzenia dna zmniejszają różnorodność i zagęszczenie nieosiadłych gatunków mejobentosowych (takich jak Nematoda i Harpacticoida), ale już po 3 latach różnorodność zwykle wraca do wyjściowych parametrów (AHNERT i SCHRIEver 2001, Jones i współaut. 2017). Jednak w badaniach przeprowadzonych 26 lat po eksperymentalnym zaburzeniu dna, różnorodność Nematoda nie wróciła do wyjściowych wartości (MILJUTiN i współaut. 2011). W przypadku innych grup zwierzat, zaburzenia również wywołują zmniejszenie różnorodności biologicznej (szczególnie Foraminifera i Polychaeta oraz organizmów megabentosowych - zarówno sesylnych jak i mobilnych) utrzymujacce się zwykle dłużej niż 7 lat (PURSER i współaut. 2016, JONES i współaut. 2017). Wykazano, że pomimo zaburzeń, różnorodność biologiczna po kilku latach zwykle wraca do stanu pierwotnego (SCHRIEVER 1995, JONES i współaut. 2017). Sa jednak takie grupy, jak m.in. gabki i przedstawiciele megafauny, których liczebność na niektórych eksperymentalnych stacjach nie wykazywała znaczacej poprawy po upływie kilku lat (JONES i współaut. 2017). Różnice wynikaja $z$ preferencji siedliskowych gatunków (JoNES i współaut. 2017), lokalnych warunków hydrogeologicznych wpływających na szybkość sedymentacji (MILJUTIN i współaut. 2011), metodyki stosowanej podczas eksperymentu (JONES i współaut. 2017) oraz intensywności zaburzeń (MILJUTIN i współaut. 2011). Przydatne przy badaniu eksperymentalnych zaburzeń dna na dużych odległościach jest wykorzystanie podwodnych zdjęć, dzięki którym można stwierdzić znaczacy wpływ na różnorodność bentosu (BLuHM 1994). Niestety, badanie możliwości odtwarzania się po zaburzeniach fauny, która ewoluowała bez większych zaburzeń przez miliony lat, jest bardzo trudne i niemiarodajne (CLARK i NEUTRA 1983, KAISER i współaut. 2017). Badania nigdy nie będa w pełni wiarygodne również dlatego, że, w porównaniu $Z$ przemysłową eksploatacją konkrecji, maja znacznie mniejsza skalę czasowa i przestrzenna (CLARK i NEUTRA 1983), obejmuja także mało liczne próbki zwierząt (BŁAŻEWICZ i współaut. 2019).

Oprócz bezpośredniego niszczenia fauny, wydobycie konkrecji polimetalicznych poskutkuje również zmiana uwarstwienia osadów oraz zmiana składu chemicznego osadów i wody, gdyż uwolnione zostana metale (zwłaszcza mangan) (BAKER i BEAUDOIN 2013). Zmiany te sa jednak trudne do oszacowania, ponieważ migracja metali $z$ wód do osadów jest zjawiskiem bardzo powolnym i wynosi ok. $1 \mathrm{~mm} /$ milion lat (OEBIUs $\mathrm{i}$ współaut. 2001).

Wzruszenie osadów, ich zawieszenie i przemieszczanie pod wpływem prąów morskich będzie miało wyraźnie negatywny wpływ na funkcjonowanie fauny na dużych powierzchniach - nawet do $300 \mathrm{~km}^{2}$ rocznie (Clark i NEUTRA 1983, Koslow 2007), gdyż osady moga być przeniesione wraz $Z$ ruchem wody nawet do $100 \mathrm{~km}$ od miejsca wydobycia (BURNS 1980, JANSSEN i współaut. 2015). Resedymentacja wzburzonych osadów będzie dużo intensywniejsza niż naturalna, co będzie miało szczególnie negatywny 
wpływ na organizmy osiadłe, które będą w ten sposób przysypywane, a organizmy filtrujące (które dominują na tych obszarach) będą miały uniemożliwiona filtrację $z$ wody zawiesiny organicznej (BURNS 1980, CLARK i NEUTRA 1983, BLUHM 1994, BAKER i BEAUDOIN 2013, AMON i współaut. 2016). Dokładne skutki przemieszczania się sedymentu nie sa dokładnie poznane i będą zależeć od tego, jakie technologie zostaną zastosowane, jak bardzo fauna będzie wrażliwa na resedymentację oraz od specyfiki fizykochemicznej wody (BAKER i BEAUDOIN 2013).

Dodatkowym negatywnym czynnikiem będzie światło, hałas i wibracje powodowane przez sprzęt wydobywczy, co będzie odstraszać głównie organizmy nektonowe (m.in. ryby), a ponadto wiele osobników będzie zderzało się $z$ kombajnami wydobywczymi (BAKER i BEAUDOIN 2013, AMON i współaut. 2016).

\section{WPEYW EKSPLOATACJI KONKRECJI POLIMETALICZNYCH NA TON OCEANICZNA}

Materiał pobrany $z$ dna będzie transportowany rurami do statku lub platformy. Sam transport w rurach nie powinien mieć negatywnego wpływu na środowisko (oprócz organizmów nektonowych, które będą ginać w wyniku przypadkowych zderzeń), ale materiał zawierajacy konkrecje, wodę i osady będzie odwadniany na statku lub platformie, po czym woda wraz $z$ osadami będzie zrzucana do oceanu, powodujac resedymentacje na bardzo dużych obszarach (BURNS 1980, OEBIUs i współaut. 2001, BAKER i BEAUDOIN 2013). Możliwe sa jednak także takie systemy, które w rurach będa dokonywać wstępnej obróbki konkrecji, polegajacej na ich rozdrobnieniu i usunięciu materiału odpadowego już na etapie transportu pionowego. Jednak nawet $w$ systemach nieprzewidujących takiego procesu, trzeba liczyć się z możliwościa uszkodzenia rur i zanieczyszczeniem wody poniżej pęknięcia (OEBIUS i współaut. 2001).

Resedymentacja stanowi duże zagrożenie nie tylko dla zwierzat osiadłych i filtrujacych, ale także dla drapieżników występujacych do głębokości 200 m, które lokalizuja swoje ofiary przy pomocy zmysłu wzroku, a przez zmętnienie wody zadanie to będzie znacznie utrudnione (OEBIUS i współaut. 2001, BAKER i BEAUDOIN 2013, KAISER i współaut. 2017). Jak pokazuja badania na dnie Pacyfiku, osady zawieszone w wodzie mogą rozprzestrzeniać się na kilkadziesiąt km i utrzymywać przez 36 godzin, a podczas zrzutu eksploatacyjnego nawet dłużej (BURNS 1980). Dodatkowo, zrzucana woda bęzie zmieniać temperature i zasolenie lokalnie, a przez trudne do przewidzenia ruchy wody, także globalnie (BURNS 1980, BAKER i BEAUDOIN 2013). Należy pamiętać, że skład chemiczny wody $z$ zanieczyszczeniami ze statków różni się od składu chemicznego wody oceanicznej - ma wyższe stężenie żelaza i manganu, zaś mniejsze stężenie wapnia (BURNS 1980).

\section{WPEYW EKSPLOATACJI KONKRECJI POLIMETALICZNYCH NA POWIERZCHNIE WODY I WYBRZEŻA}

Zarówno jednostki pływające, jak i platformy wydobywcze będą źródłem hałasu i światła odstraszajacego organizmy, a także przeszkoda, o którą będą zabijać się duże zwierzęta pływajace (BAKER i BEAUDOIN 2013, AMON i współaut. 2016). Dodatkowo, będa one generowały zanieczyszczenia wody i powietrza (BAKER i BEAUDOIN 2013). Co ważne, negatywne skutki ich obecności nie będa ograniczone wyłącznie do powierzchni oceanu nad miejscem wydobycia konkrecji, ale na całej długości transportu surowca, od miejsca eksploatacji do miejsca magazynowania na lądzie, a więc zaburzeniu będa ulegać również wybrzeża oceanów (BAKER i BEAUDOIN 2013).

Spust wody $z$ odwadniania konkrecji będzie zmętniać powierzchniowa warstwę wody, co skutecznie ograniczy dopływ promieni słonecznych w głębsze warstwy wody i zmniejszy produkcję pierwotna (BURNS 1980, BAKER i BEAUDOIN 2013). Z drugiej strony, zmiana chemizmu wody i osadów (szczególnie wzrost stężenia żelaza i azotu przy spadku zawartości wapnia) może wpłynać na zwiększenie tempa rozmnażania się mikroorganizmów samożywnych zwiazanych $z$ konkrecjami, co zwiększy produkcję pierwotna w oceanach w strefie przydennej (HYUN i współaut. 1998, VALSANGKAR 2003).

Reasumujacc, długofalowy wpływ eksploatacji konkrecji polimetalicznych na środowisko jest obecnie nie w pełni poznany (CLARK i NEUTRA 1983, JONES i współaut. 2017), choć wydaje się być on znaczny i długotrwały (Jones i współaut. 2017). Jako najważniejszy długofalowy skutek spadku bioróżnorodności dna, naukowcy wskazuja zachwianie sieci troficznych i obiegu węgla, gdyż organizmy bentosowe sa najważniejszym ogniwem troficznym środkowych, oligotroficznych części oceanów (CLARK i NEUTRA 1983).

Ocenia się, że w trakcie 20 lat operacji wydobywczych, eksploatacja może wpłynać negatywnie na obszar oceaniczny o powierzchni nie mniejszej niż 10 000-20 000 $\mathrm{km}^{2}$ (Ryc. 1) (KosLOW 2007). 


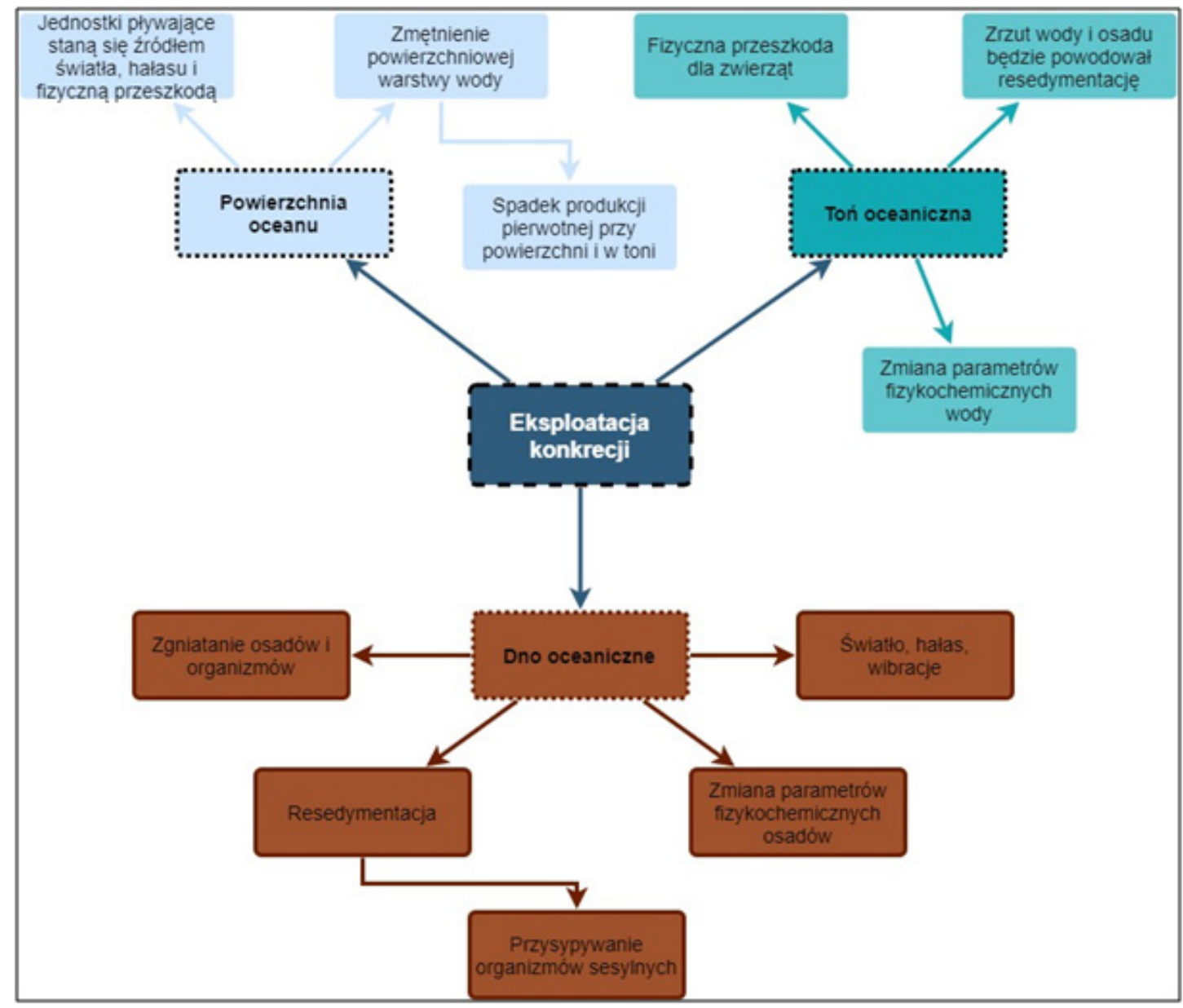

Ryc. 1 Wpływ eksploatacji konkrecji polimetalicznych na powierzchnię, toń i dno oceaniczne (wybrane elementy).

$Z$ drugiej strony, uważa się, że eksploatacja konkrecji polimetalicznych jest znacznie korzystniejsza niż wydobycie rud lądowych, nie tylko $z$ powodów społecznych i opłacalności ekonomicznej, ale także ze względu na środowisko, gdyż sprzęt wydobywający konkrecje może być użyty wielokrotnie, eksploatacja surowca wymaga znacznie mniej rozbudowanej infrastruktury, a ponadto produkuje się dużo mniej odpadów szkodliwych dla środowiska (ABRAMOWSKI i STOYANOVA 2012).

\section{DZIAŁANIA OCHRONNE}

W zwiąku $z$ dużym zainteresowaniem eksploatacja konkrecji polimetalicznych oraz wieloma badaniami wskazujacymi na negatywny wpływ kopalnictwa morskiego na środowisko, w celu ustalenia regulacji i praw własności na otwartym oceanie oraz w celu ochrony środowiska morskiego, utworzono w 1994 r. ISA (LODGE 2002, LODGE i współaut. 2014).
Na obszarze CCFZ ISA wydała w 2001 r. licencje dla 10 konsorcjów: Chin, Francji, Indii, IOM (ang. Interoceanmetal - państwa byłego bloku wschodniego m.in. Polska), Japonii, Korei Południowej, Nauru, Niemiec, Rosji i Tonga (ABRAMOWSKI i KotLIŃSKI 2011). Od niedawna liczba umów wzrosła do 26 (KIM 2017).

Kraje zainteresowane działalnością w obszarze CCZ (tzw. kontraktorzy ISA) uzyskuja 15-letnia licencję na prowadzenie badań, a $\mathrm{w}$ przyszłości również zgodę na prace wydobywcze (VANREUSEL i współaut. 2016, KAISER i współaut. 2017). Przed wydobyciem konkrecji kontraktorzy sa zobowiazani do oceny zasobów geologicznych (LODGE 2002, LODGE i współaut. 2014, VANREUSEL i współaut. 2016), lecz testom przed wydobyciem powinny towarzyszyć także badania środowiskowe (Bluhm 1994, LODGE 2002, LODGE i współaut. 2014, JANSSEN i współaut. 2015, VANREUSEL i współaut. 2016, JONES i współaut. 2017, GLOVER i współaut. 2018, BŁAŻEWICZ i współaut. 2019). Opierać się one powinny na ocenie składu, rozmieszczenia i liczebno- 


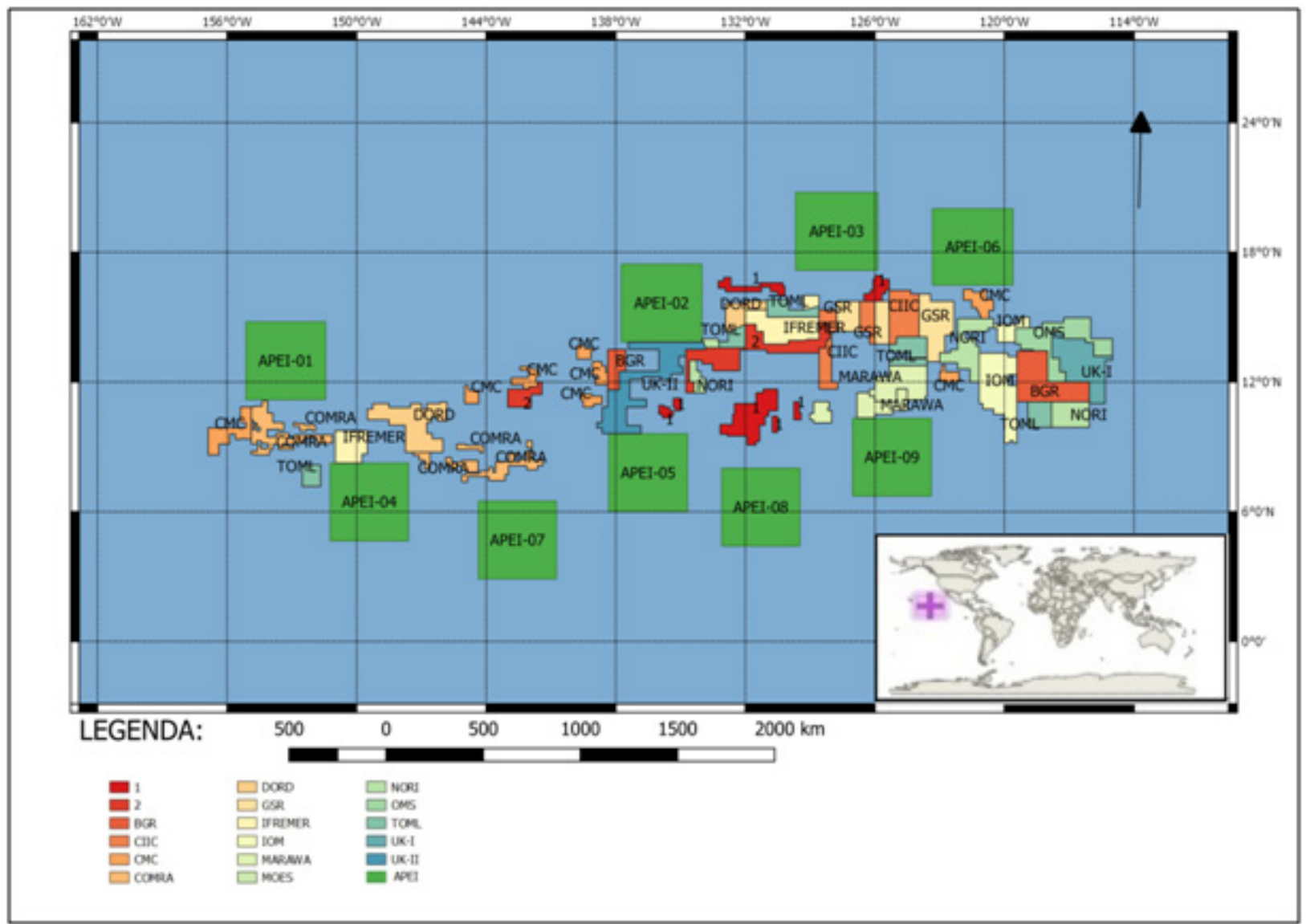

Ryc. 2 Obszar CCFZ podzielony na APEIs oraz pola eksploatacyjne należące do:

1 - Korei Południowej; 2 - Rosji (Yuzhmorgeologiya); BGR - Niemiec; CIIC - Wysp Cooka; CMC - Chin; COMRA Chin; DORD - Japonii; GSR - Belgii; IFREMER - Francji; IOM - Bułgarii, Czech, Kuby, Polski, Rosji, Słowacji (Interoceanmetal); MARAWA - Kiribati; MOES - Indii; NORI - Nauru; OMS - Singapuru; TOML - Tonga; UKI - Wielkiej Brytanii; UKII - Wielkiej Brytanii.

ści fauny. Prowadzone powinny być także regularne badania biomonitoringowe (BAKER i BeAudoin 2013, Glover i współaut. 2018), np. w 5-letnich cyklach (GLOVER i współaut. 2018). Mimo wielu nieopisanych gatunków Nematoda oraz wciąż małego poznana ich ekologii, wydają się one być dobra grupa kontrolna obszaru CCZ (LAMBSHEAD i współaut. 2003). Temu celowi mają służyć badania różnorodności takie jak Abyssline (GOODAY i współaut. 2015, AMON i współaut. 2016) oraz eksperymentalne zaburzenia dna: BIEs prowadzone przez IOM, Japonię, Rosję i USA, INDEX prowadzony przez Indie (VALSANGKAR 2003, ABRAMOWSKI i KOTLIŃSKI 2011, JANSSEN i współaut. 2015), DISCOL prowadzony przez Niemcy (AHNERT i SCHRIEVER 2001, VALSANGKAR 2003, ABRAMOWSKI i KOTLIŃSKI 2011, JANSSEN i współaut. 2015), JET prowadzony przez Japonię (JANSSEN i współaut. 2015) oraz NAVABA prowadzona przez Chiny (ABRAMOWSKI i KOTLIŃSKI 2011). Jak podaje GLOVER i współaut. (2018) ISA stworzyła wiele dobrze działajacych regulacji ochronnych, lecz wciąż brakuje pełnej wiedzy o składzie gatunkowym i różnorodności genetycznej.

Oprócz badań biomonitoringowych, bar$\mathrm{dzo}$ istotne sa również plany zarządzania środowiskowego, które maja zmniejszać wpływ kopalnictwa na środowisko oraz chronić inne obszary przed jego negatywnym wpływem, co będzie możliwe wyłącznie dzięki szerokiej współpracy różnych środowisk (BAKER i BEAUDOIN 2013, JONES i współaut. 2019). Doświadczone firmy takie jak: Pacific Community International Marine Minerals Society sugeruja, aby na obszarach wydobywczych gromadzić dane o środowisku i stosować podejście zapobiegawcze, co zostało już częściowo wprowadzone na obszarze CCFZ (JonEs i współaut. 2019). Łagodzenie skutków wydobycia konkrecji polimetalicznych powinno obejmować 4 poziomy: unikanie narażania różnorodności biologicznej, minimalizowanie jej zmniejszania, odtwarzanie i w ostateczności zrekompensowanie (VAN DOVER i współaut. 2017). Strategię taka stosuje się w przypadku górnictwa lą- 
dowego, lecz w przypadku podwodnego może nie być ona skuteczna. W szczególności idea zrekompensowania różnorodności biologicznej przez odtworzenie innych ekosystemów, np. raf koralowych, nie jest dobrym rozwiązaniem (VAN DOVER i współaut. 2017).

Szczególnie ważnych pod względem biomonitoringu i zachowania różnorodności biologicznej ma być 9 obszarów ochronnych (ang. Areas of Particular Enviromental Interest, APEI) o łacznej powierzchni ok. 1440 tys. $\mathrm{km}^{2}$, wyznaczonych na obszarze CCFZ w 2007 r. (ABRAMOWSKI i STOYANOVA 2012, LODGE i współaut. 2014). Podstawowymi założeniami było, aby (i) powierzchnia chronionych obszarów wynosiła od 30 do 50\% łacznej powierzchni zarządzanego obszaru, aby (ii) każdy obszar chroniony zawierał pełen przekrój siedlisk i taksonów zwierzat, a także, aby (iii) APEIs było dostatecznie duże, by mogły zapewniać przetrwanie fauny mimo działań eksploatacyjnych (LODGE i współaut. 2014). APEIs (Ryc. 2) posiadaja dodatkowo strefy buforowe o grubości $100 \mathrm{~km}$ przy każdym boku obszaru chronionego (LODGE i współaut. 2014). Na obszarach tych eksploatacja konkrecji polimetalicznych zostanie wstrzymana na 5 lat, a głównym ich celem sa badania środowiskowe nad wpływem eksploatacji konkrecji w sasiednich polach (LODGE i współaut. 2014). Choć resedymentacja będzie następowała również na obszarach APEI, to brak wydobycia konkrecji spowoduje, $\dot{z} \mathrm{e}$ fauna będzie je zasiedlać, dzięki czemu różnorodność w większym stopniu zostanie zachowana (VANREUSEL i współaut. 2016). Jak jednak pokazuja badania BŁAŻEWICZ i współaut. (2019), niektóre obszary APEIs nie zostały prawidłowo wyznaczone. Spośród pięciu miejsc poboru prób z CCFZ (pole BGR, pole IOM, pole GSR, pole Ifremer oraz APEI3), analizowany obszar ochronny cechował się najniższym bogactwem gatunkowym (APEI3 5 gatunków, podczas gdy BGR - 42 gatunki, IOM - 31 gatunków, GSR - 22 gatunki i Ifremer 20 gatunków). Jak twierdzi VANREUSEL i współaut. (2016), samo wyznaczenie APEIs nie rozwiazuje w pełni problemu i obszary ochronne powinny znajdować się również na polach komercyjnych. Ograniczenie wydobycia konkrecji polimetalicznych powinno obejmować również pola eksploatacyjne, na których część konkrecji nie byłaby wydobywana (OEBIUS i współaut. 2001, VAN DOVER i współaut. 2017).

Skuteczne moga okazać się również działania technologiczne, majace zmniejszyć negatywny wpływ wydobycia konkrecji na środowisko. Przykładem takich usprawnień maja być kombajny $z$ systemem zbierajacym umocowanym na czole pojazdu, aby urządzenie poruszało się po "czystym” dnie, dzięki czemu nie będzie niszczyć konkrecji i fauny (OEBIUs i współaut. 2001). Innym rozwiazaniem sa kombajny $z$ osłonami ograniczajacymi rozprzestrzenianie się wzruszonych osadów (VAN DOVER i współaut. 2017).

Działania ochronne i prawidłowe zarzadzanie obszarami eksploatacyjnymi, rozwiązania technologiczne i wyznaczenie obszarów ochronnych, przy jednoczesnym biomonitoringu, sa bardzo potrzebne. Jednak, jak wskazuje KIM (2017), przed rozpoczęciem wydobycia konkrecji polimetalicznych na skalę przemysłowa, powinno się dokładniej przeanalizować doniesienia naukowe, ponieważ odniesione korzyści moga okazać się mniejsze niż straty spowodowane eksploatacja (KIM 2017). Naukowcy wyraźnie jednak podkreślaja, że nie ma możliwości, aby działania wydobywcze nie zmniejszały różnorodności biologicznej (VAN DOVER i współaut. 2017).

Streszczenie

W niniejszej pracy zaprezentowano przegląd literatury poświęconej wyzwaniom środowiskowym zwiąanym z eksploatacja konkrecji polimetalicznych. Scharakteryzowano specyfikę powstawania, składu chemicznego i lokalizacji konkrecji. Przedstawiono przegląd najważniejszych grup mikro-, mejo-, makro- i megabentosowych zwiazanych z konkrecjami. Scharakteryzowano różnorodność biologiczną i unikatowość fauny w porównaniu $z$ innymi częściami oceanów. Zwrócono szczególną uwagę na relacje pomiędzy obecnościa konkrecji polimetalicznych a występowaniem unikatowej fauny sesylnej i szczelinowej. Przedstawiono najważniejsze etapy planowanej eksploatacji konkrecji oraz zagrożenia dla środowiska pojawiajace się na każdym $z$ nich. Scharakteryzowano najważniejsze zagrożenia środowiskowe na dnie oceanicznym, w toni oceanicznej oraz na powierzchni oceanów i na wybrzeżach. Zaprezentowano podejmowane obecnie działania na rzecz ochrony tych środowisk, w kontekście czego zwrócono szczególna uwagę na obszary ochronne (APEIs) i podkreślono potrzebę prowadzenia regularnych badań biomonitoringowych.

\section{LITERATURA}

ABRAmowski T., Kotliński R. A., 2011. Współczesne wyzwania eksploatacji oceanicznych kopalin polimetalicznych. Górnictwo i Geoinżynieria 35, 41-61.

ABRAMOWSKI T., STOYANOVA V., 2012. Deep-sea polymetallic nodules: renewed interest as resources for environmentally sustainable development. Proc. In. Multidiscip. Scient. GeoConference SGEM 1, 515-521.

AHNERT A., SCHRIEVER G., 2001. Response of abyssal Copepoda Harpacticoida (Crustacea) and other meiobenthos to an artificial disturbance and its bearing on future mining for polymetallic nodules. Deep-Sea Research II 48, 3779-3794.

Amon D. J., Ziegler A. F., DAhlgren T. G., Glover A. G., GoINEAU 'A., GoOdAy A. J., WIKLUND H., SMITH C. R., 2016. Insights into the abundance and diversity of abyssal megafauna in a polymetallic-nodule region in the eastern Clarion-Clipperton Zone. Sci. Rep. 6, 1-12. 
BAKER E., BEAUdoin Y., 2013. Deep Sea Minerals: Manganese Nodules, a physical, biological, en vironmental, and technical review. Secretariat of the Pacific Community 1B, 1-51.

BlÖTHe M., WEgORZEWSKI A., MÜller C., SIMON F., KUHN T., SCHIPPERS A., 2015. Manganese-cycling microbial communities inside deep-sea manganese nodules. Environ. Sci. Technol. 49, 7692-7700.

BLUHM H., 1994. Monitoring megabenthic communities in abyssal manganese nodule sites of the East Pacific Ocean in association with commercial deep-sea mining. Aquatic Conserv. Marine Freshwater Ecosyst. 4, 187-201.

BŁAŻEWICZ M., JÓŹWIAK P., MENOT L., PABIS K. 2019. High species richness and unique com position of the tanaidacean communities associated with five areas in the Pacific polymetallic nodule fields. Progr. Oceanogr. 176, 1-7.

BURNS R. E., 1980. Assessment of environmental effects of deep ocean mining of manganese nodules. Helgoländer Meeresunters 33, 433442.

Clark J. P., NEUTRA M. R., 1983. Mining manganese nodules. Potential economic and environmental effects. Resource Policy 9, 99-109.

De Smet B., PAPE E., Riehl T., Bonifácio P., ColSON L., VANREUSEL A., 2017. The community structure of deep-sea macrofauna associated with polymetallic nodules in the eastern part of the Clarion-Clipperton Fracture Zone. Front. Mar. Sci. 4, doi: 10.3389/fmars.2017.00103.

DugOLINSKY B. K., 1976. Chemistry and morphology of deep-sea manganese nodules and the significance of associated encrusting protozoans on nodule growth. $\mathrm{PhD}$ thesis, University of Hawaii.

Glover A. G., Dahlgren T. G., Wiklund H., MOHRBECK I., SMith C. R., 2016a. An end-toend DNA taxonomy methodology for benthic biodiversity survey in the Clarion-Clipperton Zone, Central Pacific Abyss. J. Marine Sci. Engin. 4, 1-34.

Glover A. G., Dahlgren T. G., Taboada S., PeTERSON G., WIKLUND H., WAESCHENBACH A., Cobley A, Martínez P., KaISER S., SchnurR S., KHODAMI S., RASCHKA U., KERSKEN D., STUCKAS H., MENOT L. i współaut., 2016b. The London workshop on the biogeography and connectivity of the Clarion-Clipperton Zone. Res. Ideas and Outcomes 2, doi: 10.3897/rio.2.e10528.

Glover A. G., Wiklund H., Chen C., DAHLGRen T. G., 2018. Managing a sustainable deep-sea 'blue economy' requires knowledge of what actually lives there. eLife $7,1-7$.

GoOdAY A. J., GOINEAU A., VOLTZKI I., 2015. Abyssal foraminifera attached to polymetallic nodules from the eastern Clarion Clipperton Fracture Zone: a preliminary description and comparison with North Atlantic dropstone assemblages. Marine Biodivers. 45, 391-412.

HAN X., SHEN H., Chen J., QIAN J., 1997. Biogenesis and binary mineralization of organism and chemism of polymetallic nodules from $\mathrm{Pa}$ cific Ocean. Sci. China 40, 656-661.

Hyun J. H., KIM K. H., Jung H. S., LEE K. Y., 1998. Potential environmental impact of deep seabed manganese nodule mining on the Synechococcus (cyanobacteria) in the Northeast Equatorial Pacific: effect of bottom water-sediment slurry. Marine Geores. Geotechnol. 16, 133-143.

JANSSEN A., Kaiser S., MEIBNER K., BRenke N., MENOT L., ARBIZU P. M., 2015. A reverse taxonomic approach to assess macrofaunal distri- bution patterns in abyssal Pacific polymetallic nodule fields. PLoS One 10, 1-26.

Jones D. O. B., KaISER S., SweEtman A. K., Smith C. R., Menot L., Vink A., TRueblood D., Greinert J., Billett D. S. M., ArbizU P. M., RADZIEJEWSKA T., SiNGH R., INGOLE B., STRATMANN T., Simon-Lledó E., DuRden J. M., ClARK M. R., 2017. Biological responses to disturbance from simulated deep-sea polymetallic nodule mining. PLoS One 12, 1-26.

JoNes D. O. B., DURDEN J. M. MURPHY K., GJerde K. M., Gebicka A., Colaço A., MorAto T., Cuvelier D., Billett D. S. M., 2019. Existing enviornmental management approaches relevant to deep-sea mining. Marine Policy 103, 172-181.

KAISER S., SMith C. R., ARBIZU P. M., 2017. Editorial: Biodiversity of the Clarion Clipperton Fracture Zone. Marine Biodivers. 47, 259-264.

KIM R. E., 2017. Should deep seabed mining be allowed? Marine Pol. 82, 134-137.

KodAGALI V., 1988. Influence of regional and local topography on the distribution of polymetallic nodules in Central Indian Ocean Basin. Geo-Marine Letters 8, 173-178.

KotLiŃSKI R. A., 2011. Pole konkrecjonośne Clarion-Clipperton - źródło surowców $w$ przyszłości. Górnictwo i Geoinżynieria 35, 195-214.

KotlińsKI R. A., MACIAGG Ł., ZAWADZKI D., 2015. Potential and recent problems of the possible polymetallic nodules in the ocean deposites. Gieołogija i Poleznyje Iskopajemyje Mirowogo Okieana 2, 65-80.

KosLow T., 2007. The silent deep. The discovery, ecology and conservation of the deep sea. University of New South Wales Press Ltd.

LAMBShead P. J. D., Brown C. J., FERRERO T. J., HAWKInS L. E., SMITH C. R., MitChELl N. J., 2003. Biodiversity of the nematode assemblages from the region of the Clarion-Clipperton Fracture Zone, an area of commercial mining interest. BMC Ecol. 3, 1-12.

Li Y., SONG H., LI J., YAO X., 1997. Relationship between polymetallic nodules and submarine hydrothermalism in the Central Pacific Ocean. Chinese Sci. Bull. 42, 1-5.

Lim S. C., WiKLUND H., Glover A. G., DAHLGReN T. G., TAN K. S., 2017. A new genus and species of abyssal sponge commonly encrust ing polymetallic nodules in the Clarion-Clipperton Zone, East Pacific Ocean. Syst. Biodivers. $15,507-519$

LODGE M. W., 2002. International Seabed Authority's Regulations on prospecting and exploration for polymetallic nodules in the area. J. Energy Nat. Resour. Law 20, 270-295.

LOdGe M., Johnson D., LE GuRun G., WengleR M, Weaver P., GunN V., 2014. Seabed mining: International Seabed Authority environmental management plan for the Clarion-Clipperton Zone. A partnership approach. Marine Policy 49, 66-72.

Mewes K., Mogollón J. M., PicARD A., RÜHLeMANN C., KuHN T., NÖTHEN K., KASTEN S., 2014. Impact of depositional and biogeochemical processes on small scale variations in nodule abundance in the Clarion-Clipperton Fracture Zone. Deep-Sea Res. I 91, 125-141.

MiluUtin D. M., MiluUtina M. A., ARBIZU P. M., GALÉRON J., 2011. Deep-sea nematode assemblage has not recovered 26 years after experimental mining of polymetallic nodules (Clarion-Clipperton Fracture Zone, Tropical Eastern Pacific). Deep-Sea Res. I 58, 885-897.

Miluutina M. A., MiluUtin D. M., Mahatma R. GALÉRON J., 2010. Deep-sea nematode assem- 
blages of the Clarion-Clipperton Nodule Province (Tropical North-Eastern Pacific). Marine Biodivers. 40, 1-15.

MULLINEAUX L.S. 1987. Organisms living on manganese nodules and crusts: distribution and abundance at three North Pacific sites. DeepSea Res. 34, 165-184.

MORNANT J. R., GOURBAULT N., 1990. Evaluation of abyssal meiobenthos in the eastern central Pacific (Clarion-Clipperton fracture zone). Prog. Oceanogr. 24, 317-329.

OEBIUS H. U., BECKER H. J., ROLINSKI S., JANKOWSKI J. A., 2001. Parametrization and evaluation of marine environmental impacts produced by deep-sea manganese nodule mining. Deep-Sea Research II 48, 3453-3467.

Pautot G., Melguen M., 1975. Deep bottom currents, sedimentary hiatuses and polymetallic nodules. Papers presented at the I.D.O.E Workshop Suva, Fiji, 1-6 September, 227234.

Purser A., Marcon Y., Hoving H. J. T., VecchiONE M., PIATKOWSKI U., EASON D., BluHM H., Boztius A., 2016. Association of the deepseas incirrate octopods with the manganese crusts and nodule fields in the Pacific Ocean. Curr. Biol. 26, 1268-1269.

RADZIEJEWSKA T., KOTLIŃSKI R., 2002. Acquiring marine life data while experimentally assessing environmental impact of simulated mining in the deep sea. ICES CM 1, 1-14.

SCHRIEVER G., 1995. DISCOL - Disturbance and recolonization experiment of a manganese area of the Southeastern Pacific. International Society of Offshore and Polar Engineers.

Shulse C. N., Maillot B., SMith C. R., Church M. J., 2017. Polymetallic nodules, sediments, and deep waters in the equatorial North Pacific exhibit highly diverse and distinct bacterial, archaeal, and microeukaryotic communities. MicrobiologyOpen 6, 1-16.
SzAMAŁEK K. 2018. Udziat Polski w pracach Miedzynarodowej Organizacji Dna Morskiego. Przegl. Geol. 66, 185-188.

Thiel H., Schrevier G., Bussau C., Borowski C., 1993. Manganese nodule crevice fauna. DeepSea Res. 40, 419-423.

VALSANGKAR A. B., 2003. Deep-sea polymetallic nodule mining: challenges ahead for technologists and environmentalists. Marine Geores. Geotechnol. 21, 81-91.

Vanreusel A., Hilario A., Ribeiro P. A., Menot L., ARBizU P. M., 2016. Threatened by mining, polymetallic nodules are required to preserve abyssal epifauna. Sci. Rep. 6, 1-6.

VAN DOVER C. L., ARDRON J. A., Escobar E., GIANNI M., GJerde K. M., JAECKel A., Jones D. O. B., Levin L. A., Niner H. J., PENDleton L., SMith C. R., Thiele T., TuRner P. J., Watling L., Weaver P. P. E., 2017. Biodiversity loss from deep-sea mining. Nat. Geosci. 10, 464465.

WANG X., Schlossmacher U., Wiens M., SCHRÖDER H. C., MÜllER W. E. G., 2009. Biogenic origin of polymetallic nodules from the Clarion-Clipperton Zone in the eastern pacific ocean: electron microscopic and EDX Evidence. Marine Biotechnol. 11, 99-108.

WANG C. S., LIAO L., XU H. X., XU X. W., WU M., ZHU L. Z., 2010. Bacterial diversity in the sediment from polymetallic nodule fields of the Clarion-Clipperton Fracture Zone. J. Microbiol. 48, 573-585.

Wu Y. H., Liao L., Wang C. S., Ma W. L., Meng F. X., WU M., XU X. W., 2013. A comparison of microbial communities in deep-sea polymetallic nodules and the surrounding sediments in the Pacific Ocean. Deep-Sea Res. I 79, 4049.

ZHANG Z., DU Y., GaO L., ZhaNG Y., SHI G., LIU C., ZHANG P., DUAN X., 2012. Enrichment of REEs in polymetallic nodules and crusts and its potential for exploitation. J. Rare Earths 30, 621-626.

KOSMOS Vol. 69, 2, 361-371, 2020

KRZYSZTOF PODWYSOCKI

Department of Invertebrate Zoology and Hydrobiology, University of Lodz, 12/16 Banacha Str., 90-237 Eódź, E-mail: krzysztof. podwysocki.biol@gmail.com

INFLUENCE OF POLYMETALLIC NODULES MINING ON BIODIVERSTY

Summary

This paper presents a review of the literature on environmental challenges related to the exploitation of polymetallic concretions. The specificity of the formation, chemical composition and location of the concretions was characterized. An overview of the most important micro-, meo-, macro- and megabenthic groups associated with concretions is provided. The biodiversity and uniqueness of the fauna has been characterized in comparison with other parts of the oceans. Particular attention was paid to the relationship between the presence of polymetallic concretions and the occurrence of unique sesile and crevice fauna. The most important stages of the planned exploitation of the concretion and environmental hazards appearing on each of them are presented. The most important environmental threats on the ocean floor, in the ocean depths and on the surface of the oceans and on the coasts have been characterized. Actions currently taken to protect these environments are presented, in the context of which special attention has been paid to conservation areas (APEIs) and the need to conduct regular biomonitoring research has been emphasized. 
